\title{
Banking Regulation Of Western Balkan Countries
}

\author{
Denada HAFIZI ${ }^{1}, \mathrm{PhD}$ Candidate \\ Irjan BUSHI ${ }^{1}$, MBA Student
}

\begin{abstract}
The current global economic crisis has affected the development of banking system in Western Balkan Countries, including Italy and Greece. These effects are expressed with the contraction of lending, fallen of foreign direct investments, fallen of the volume of remittances and fallen of international trade. The banking system continually faces new challenges in a dynamically changing financial system, and this makes difficult the implementation of bank regulation and supervision.

All the countries have improved their banking regulation in order to avoid the contagion effect among banks and banking system in general, effects that get increased especially when banks are engaged in international banking. The standardization of regulatory requirements provides potential solution to the problems of regulating international banking. So, there is a moving through agreements like Basel Accords.

For all these countries will be a comparison of regulatory capital to risk-weighted assets ratio and of capital to assets ratio in order to find out how well is capitalized their banking system. The sources of data are the reports of International Monetary Fund for a time series of 2008-2013. In the end there are some conclusions for the main problems that the implementation of supervision and bank regulation faces.
\end{abstract}

Keywords: Basel Accords, Capital Ratio, Banking Regulation

\section{Introduction:}

According to "Financial Market and Institutions" (F.C. Mishkin and Stanley G. Eakins, 2006) the definition of capital ratio and regulatory capital to RWA are as below: Capital ratio is the amount of capital divided by bank's total assets which are not riskweighted, and it measures capital adequacy of the deposit -taking sector.

To be classified as well capitalized, a bank's capital ratio must exceed 5\%; a lower capital ratio, especially below 3\% triggers increased regulatory restrictions on the bank.

Regulatory Capital to Risk Weight Assets is the amount of capital divided by riskweighted assets. Basel accords required that banks should hold as capital at least $8 \%$ of their risk-weighted assets.

The Basel II framework has four important elements: (i) maintaining the capital adequacy ratio (CAR) for the banking sector; (ii) adjusting the capital adequacy decision relating to term debt instruments in line with Basel II; (iii) introducing a capital conservation buffer, thereby prohibiting profit distribution for banks with CARs ; and (iv) adjusting the calculation of bank's regulatory capital adequacy. 
The implementation of Basel III requires an increase of capital ratio from $5 \%$ to $8 \%$ $10.5 \%$, while capital to risk assets remain the same.

\section{An overview of banking regulation}

According to IMF countries report below are some actions taken from every country:

Albania: Spillovers from the euro zone crisis and minimizing negative feedback from a slowing economy will require close banking supervision and continued close cooperation with foreign regulatory authorities. The problem of rapidly rising nonperforming loans should be addressed by clearing unpaid government bills and improving collateral execution.

The banking crisis in Greece has impacted Greek subsidiaries since Greek banks account for one-fifth of Albania's banking system, though the effects have been mitigated. Even though Greek subsidiaries constitute less than 1\% of their parents' assets, they experienced some parent funding stress, deterioration in asset quality because of problem loans to entities connected to Greece and falling remittances, and decline in profitability. Greek subsidiaries responded by shrinking their balance sheets and slowing lending.

To address possible risks, the BoA has applied more stringent capital and liquidity requirements on Greek banks, and heightened coordination with Greek authorities. The authorities view continued close bank supervision and cooperation with regional regulatory authorities as critical in containing risks so far and planned to further strengthen these efforts.

The banking system has been resilient so far, with banks having high liquidity and capital ratios.

Bosnia and Herzegovina: The banking system is relatively stable. The banking system is predominantly owned by Austrian and Italian banks, remains profitable and adequately capitalized at the aggregate level.

A sharp decline in economic activity could require bank recapitalization. Bank recapitalization could be problematic in the absence of parent bank support.

Banking laws are planned in order to fully harmonize them with EU legislation. This process was expected to be completed in the first half of 2014. Basel I has been implemented until 2009. Basel I and Basel II are applied simultaneously in 2010.

Bulgaria: The banking system is stable and liquid but nonperforming loans are rising. The local financing of Greek banks also improved and their share of assets has declined, but the two largest Greek banks still account a high level of total system assets. Specific provisions are calculated according to a BNB methodology that impress an expected loss model and are deducted from regulatory capital. Specific provisions build additional capital buffers which can be used to absorb losses, including from NPLs, provided that minimum capital adequacy requirements are not breached.

Croatia: The authorities explained that Basel III requirements could be easily met by the major banks. In fact, Basel III would allow lower capital adequacy rates than the current Croatian requirements; however, the CNB intends to explore the option of requiring more capital if needed from individual banks.

The CNB should maintain high statutory capital buffers, call for raising banks' capital early on if needed, to ensure adequate provisioning for NPLs, and further strengthen cross-border supervisory cooperation. The largely foreign-owned banking system 
remains well capitalized, although growing non-performing loans have started consuming profitability.

Financial sector appears well-capitalized and resilient to shocks, but faces risks related to potential further deterioration of asset quality, indirect credit risk deriving from vulnerable borrowers and sizeable dependence on parent banks for funding. They stressed the importance of maintaining high statutory capital buffers, ensuring adequate provisioning for non-performing loans, further strengthening financial supervision and regulation and cross-border supervisory cooperation, and closely monitoring liquidity and credit developments. Basel II is introduced in 2010.

Greece: Banks have responded to these pressures by increased recourse to exceptional liquidity support, deleveraging, and mergers to cut costs. As of midDecember, central bank funding amounted to $€ 129$ billion, up from $€ 121$ billion at end2011. With the ECB having disqualified most Greek banks from accessing the monetary policy operations window due to capital adequacy ratios below the minimum requirement, the funding comes almost entirely in the form of more expensive ELA. The government has supported banks eligible for public aid with bridge recapitalization, and has also stepped up its resolution work. The BoG completed a strategic assessment of the banking sector in March 2012 and identified four "core" banks as viable based on regulatory criteria and an assessment of their business fundamentals.

To minimize resolution costs, the authorities will develop an approach for the management of assets left in bad banks.

Italy: With limited access to wholesale funding, Italian banks continue to rely heavily on Euro system financial support. To remain resilient to the downturn, banks need to maintain adequate capital and liquidity buffers. Increasing NPLs due to recession, especially from the weak SME and construction sectors, would erode banks' capital base.

Italian banks continue to benefit from their large and stable retail funding base, traditional lending model which has limited exposures to risky assets and low leverage. The elasticity of the system has also been supported by firm supervision and regulation. So, Italian banks emerged relatively unscathed from the global financial crisis and have strengthened their capital base without large-scale equity support from the government. Throughout the global and debt crisis, the Italian banking system has remained broadly elastic, reflecting prudent risk management practices, and effective supervision.

Republic of Kosovo: Kosovo's financial system remains well-capitalized, profitable, and liquid.

Additional deleveraging by euro area parent banks with subsidiaries in Kosovo is a risk for Kosovo. While parent banks would not withdraw funding local banks are deposit funded and do not depend on resources from their parents efforts to preserve riskweighted capital could decrease credit supply by some banks.

Macedonia, FYR: Prudential regulation has remained appropriately conservative, contributing to stability without preventing credit growth. In line with peer countries macro prudential policies were tightened at the onset of the crisis. Reserve requirements were raised to limit credit growth. The interest rate cap legislation is among the easiest structural factor to tackle. Amending the legislation would allow for proper credit risk differentiation among riskier borrowers, enabling banks with good credit assessment mechanisms to better price risk in this segment, hence broadening access to 
finance. To safeguard borrowers, the law could be complemented by the best targeted consumer protection, in line with regulation in European peers.

Montenegro: The weakened economy contributed to a strong rise in nonperforming loans (NPLs). Banks were forced to increase loan loss provisioning as a result of the increasing number of NPLs, and to draw on their capital buffers. Parent banks have to date supported their Montenegrin subsidiaries with substantial additional funding and capital injections, as a result, the capital adequacy ratio was in optimal point. The World Bank has helped the authorities strengthen their banking system, and it is now governed by a modern legislative and regulatory framework and central institutions that are more resilient to future shocks.

Hence, given the limited scope for the use of conventional monetary policy instruments, the central bank focused its policy actions on improving the regulatory and supervisory framework.

Romania: The banking system is $80 \%$ foreign owned (Austrian banks dominate with 38 percent of system assets and subsidiaries of Greek banks hold about 14 percent of system assets). Compared to regional peers, foreign bank deleveraging has been moderate thus far. Bank capitalization has remained strong. Despite increasing strains, the Romanian banking sector maintains significant buffers to deal with further pressures. Reflecting continued shareholder support and retained earnings, the capitalization of the banking sector remained strong. All banks except one have a capital ratio above the regulatory minimum of 10 percent. Four Greek banks continue to exhibit capital buffers exceeding the system average, inter alia owing to capital injections from parent banks.

The Romanian financial sector so far has weathered well the impact of the economic challenges.

Serbia: This includes developing local financial markets to facilitate FX hedging and maintaining adequate liquidity and capital buffers in the banking system. Improving the regulatory framework, preparations were on track for the scheduled implementation of Basel II framework by December 2011, which will strengthen further banking sector's standards in corporate governance, risk management, capital management, and transparency. In the context of Basel II adoption, the NBS is also reviewing the banks' asset classification and provisioning regime, aiming to relax somewhat the conservative provisioning rules adopted during the pre-crisis period to put a brake on rapid credit growth.

The adoption the Basel II framework will also result in a welcome upgrade of the banking sectors' standards in corporate governance, risk management, capital management, and transparency. The Basel II framework is adopted in the end of 2011.

\section{Data for 2008-2013}

Bank Regulatory Capital to Risk Weight Assets for years 2008-2013 according to IMF data for every country in Western Balkan is as below: 
Figure 1 (2008-2013)

\section{8}

30,0

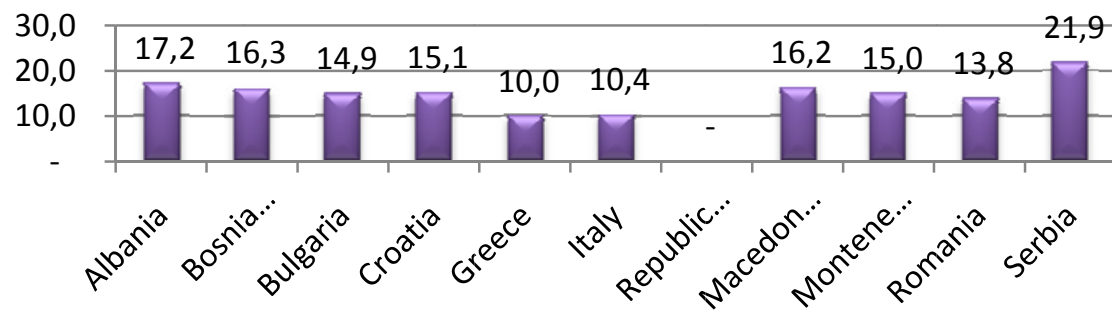

2009

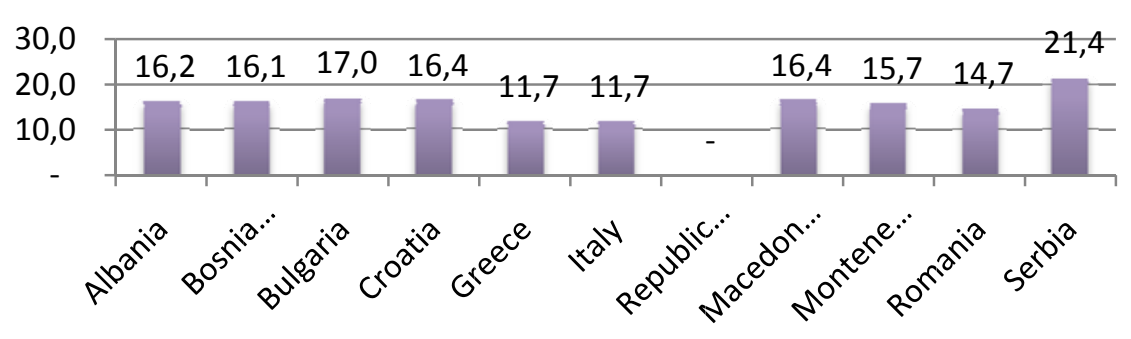

2010

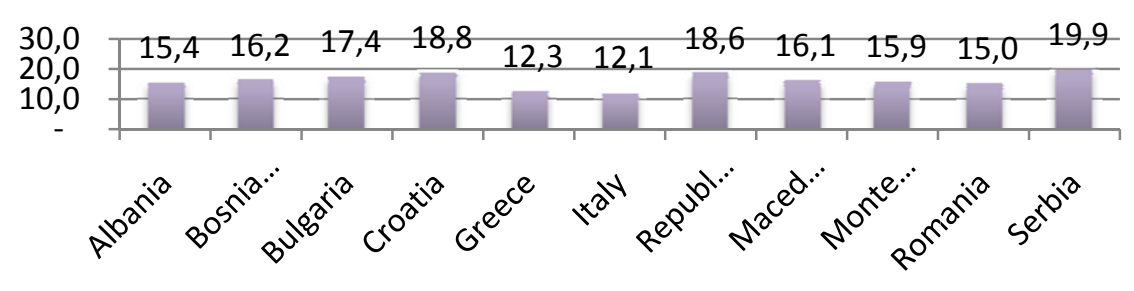

2011

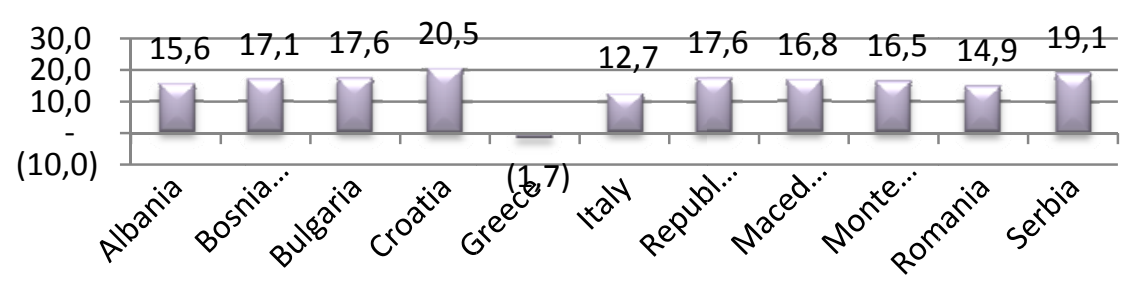




\section{2}

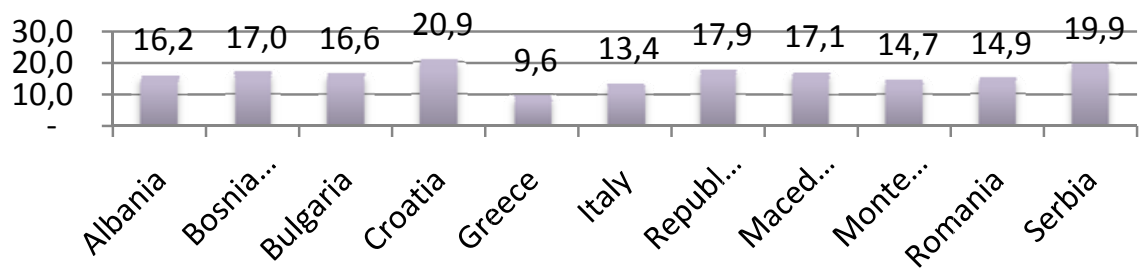

\section{3}

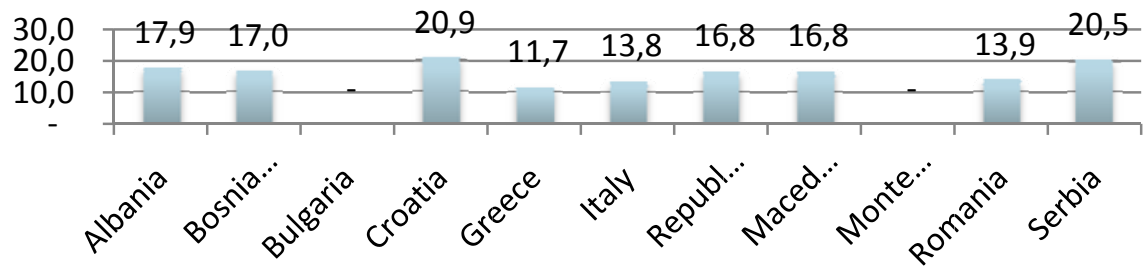

For 2008, from graphs we see that Greece has the lowest ratio (10\%). Serbia $(21.9 \%)$ and Albania (17.2\%) have the highest ratio. While Kosovo has no value because Kosovo was under the governance of Serbia. From 2010 and after we see that Kosovo its own values and are very good in comparison with the region. In the same time we see that this ratio has decline for Serbia.

Greece has a decline of this ration from 2010 with $12.3 \%$ to $-1.7 \%$ because of the financial crisis in this country.

For 2011-2013, the highest ratio have Croatia and Serbia.

In an average for a period from 2008-2013 we see that Serbia has the highest ratio $20.5 \%$, followed from Croatia with 18.77\%, Bosnia and Herzegovina 16.62\%, Macedonia FYR 16.57\%, Albania 16.42\%, Romania 14.53\%, Bulgaria 13.92\%, Montenegro 12.97\%, Italy $12.35 \%$, Republic of Kosovo $11.82 \%$ and in the end Greece $8.93 \%$.

Below is the commulative graph in order to see the trend for these six years:

Considering the cumulative trend of indicator Regulatory Capital to Risk Weight Assets for years 2008-2013 we notice that Albania, Bosnia and Herzegovina, Macedonia, Montenegro and Romania have a stable trend. From this we can think that the central banks have implemented the appropriate policy and this due the less exposition with the other countries where the crisis was in high levels. Croatia and Italy seem that have increased the enforcement the framework of capital requirements. Greece is the only country that has decreased to negative. Serbia is the first range among all these countries, that crisis has not affected. 
Figure 2 (2008-2013)

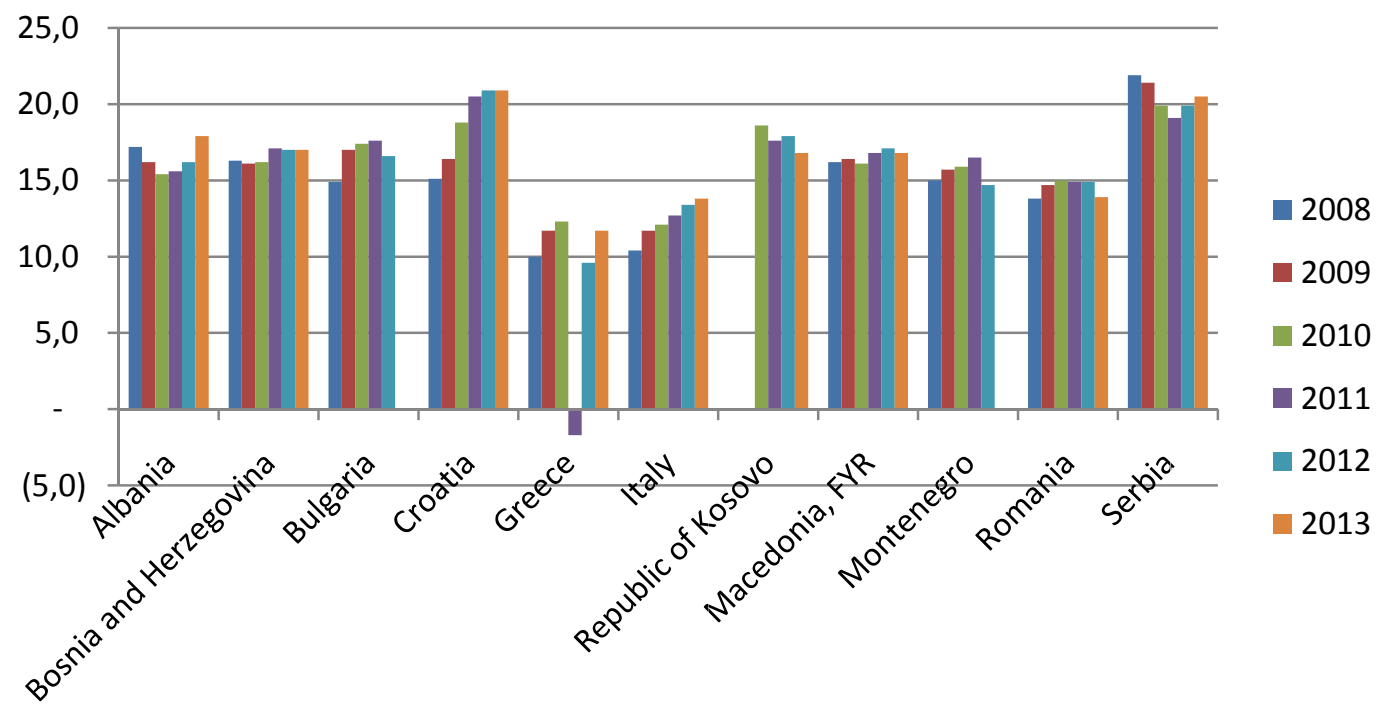

An adverse trends in this ratio may be a signal of increase of exposure to risk and possible capital adequacy problems. Capital to Assets for years 2008-2013 according to IMF data for every country in Western Balkan is as below:

Figure 3 (2008-2013)

\section{8}

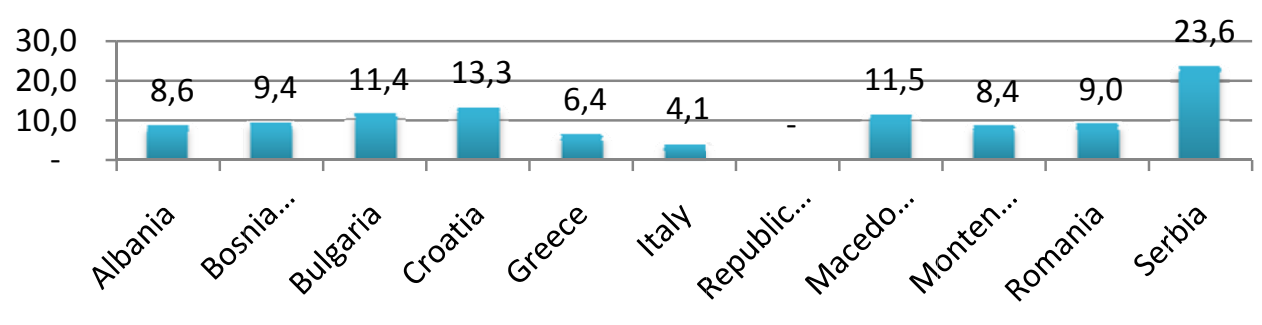

\section{9}

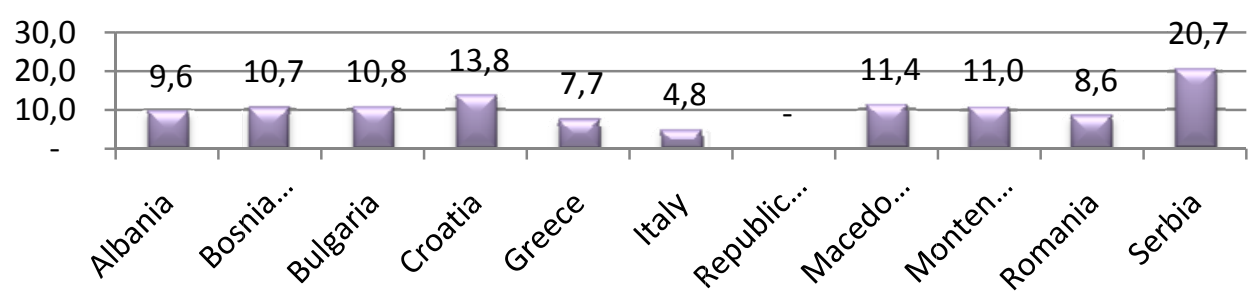




\section{0}

30,

20,0

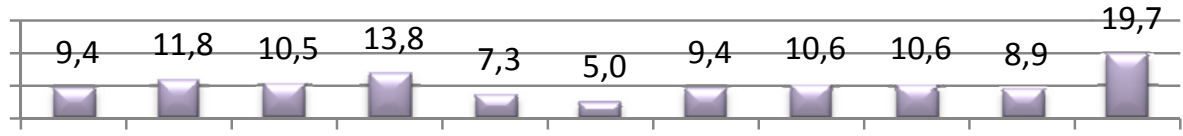

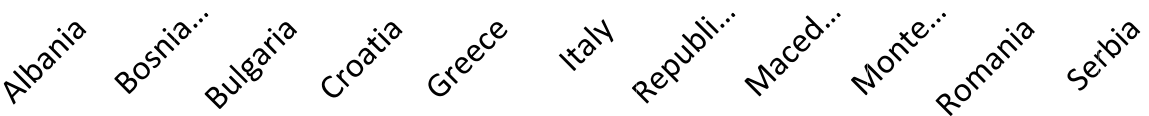

2011

30,0

20,0

10,0

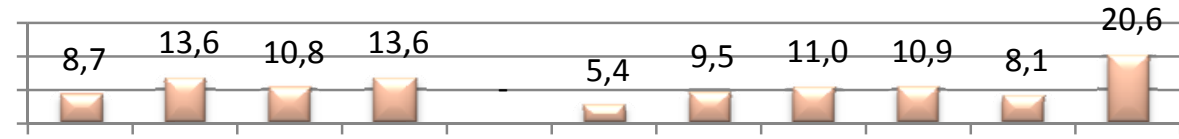

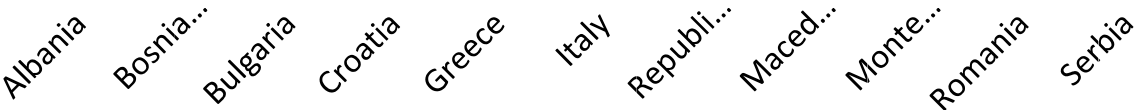

2012

30,0

20,0

10,0

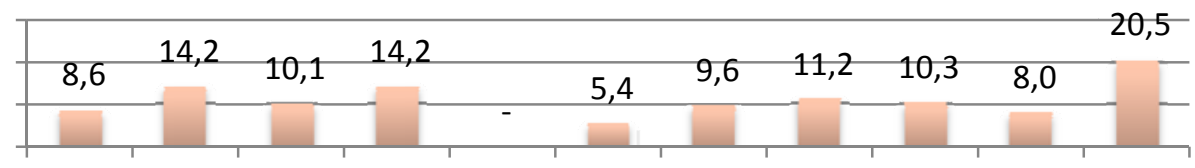

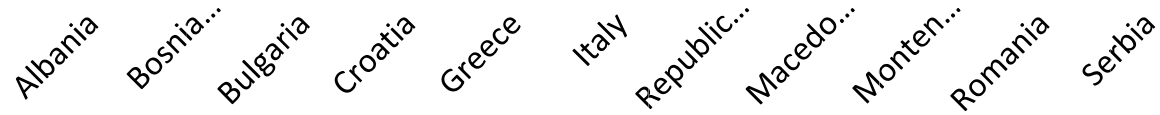

2013

30,0

20,0

10,0

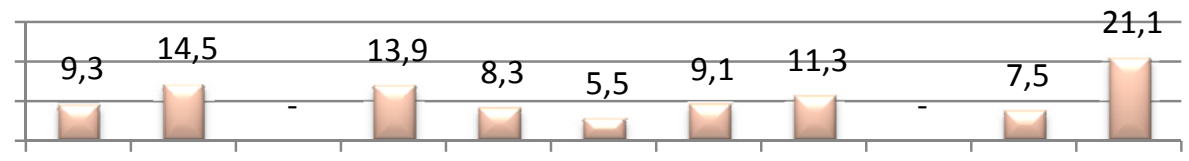

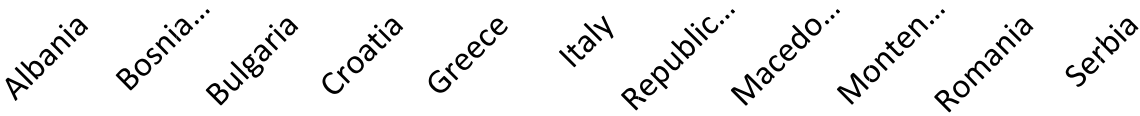


For 2008, from graphs we see that Italy has the lowest ratio (4.1\%). Serbia $(23.6 \%)$ and Crotia $(13.3 \%)$ have the highest ratio. While Kosovo has no value because Kosovo separate from Serbia in 17.02.2008. From 2010 and after we see that Kosovo its own values and are relatively good in comparison with the region. In the same time we see that this ratio has a slight decline for Serbia.

For Greece bank capital was negative for 2011-2012, because of the financial crisis in this country.

For 2011-2013, the highest ratio have Croatia and Serbia.

In an average for a period from 2008-2013 we see that Serbia has the highest ratio 21\%, followed from Croatia with 13.8\%, Bosnia and Herzegovina 12.4\%, Macedonia FYR $11.2 \%$, Albania 9\%, Bulgaria 8.9\%, Montenegro 8.5\%, Romania 8.4\%, Republic of Kosovo 6.3\%, Italy 5\%, and in the end Greece 4.9\%.

Below is the commulative graph in order to see the trend for these six years:

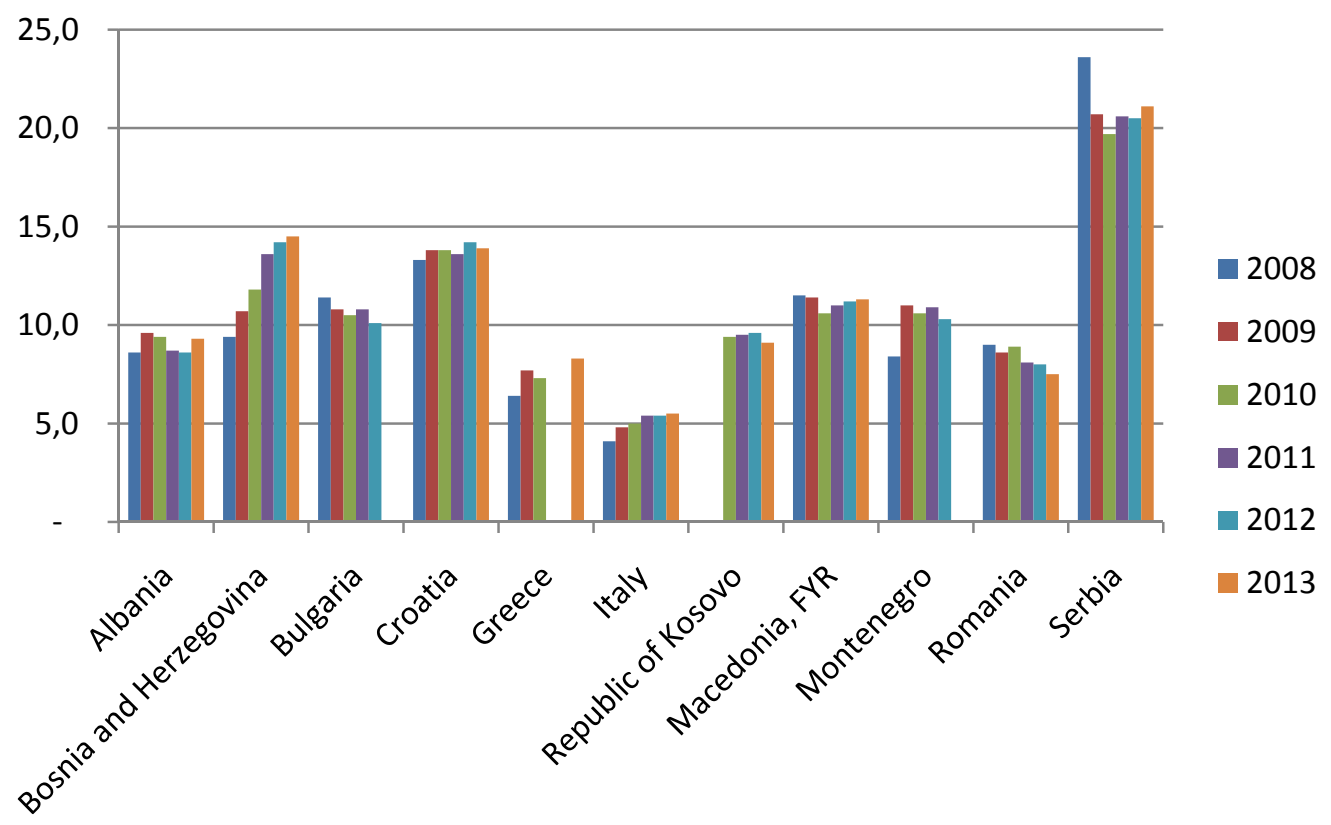

Considering the cumulative trend of indicator Capital to Assets for years 2008-2013 we notice that Albania, Bulgaria, Croatia, Italy, Republic of Kosovo, Macedonia and Romania have a stable trend. From this we can think that the central banks have implemented the appropriate policy and this due the less exposition with the other countries where the crisis was in high levels. Bosnia and Herzegovina and Montenegro seem that have increased the enforcement the framework of capital requirements. Also, even in this indicator, Greece is the only country that has decreased to the lowest levels. Serbia is the first range among all these countries, that crisis has not affected. 


\section{Conclusion}

The banking system continually faces new challenges in a dynamically changing of financial system. So, the two indicators analyzed for all these countries in a time series from 2008-2013, gives only one little part of the stability of banking system.

There is a significant contagion effect between economies (impacted by Greece economy) to all those countries where Greek banks operate. There should be a close coordination with other national regulators about evolving challenges, including regional deleveraging.

Based on these data we can express some thoughts about the main regulation that these countries have implemented to their banking system in order to be protected from the impact of the global crisis and from the crisis of the neighbor countries like Greece.

Considering all the reports for these countries, except Greece, all the other countries have managed the global crisis.

Albania makes regulatory changes introduced in late 2011, and this have helped to protect the economy against possible contagion effects, particularly related to Greece. The adequate capitalization, the increase in NPLs had been rather manageable so far.

Supervisors should be vigilant to ensure that banks continue to proactively recognize and provision against nonperforming loans and ensure that capital and liquidity levels provide appropriate buffers.

Unlike many countries in the region, the global crisis didn't affect Albania in comparison with other countries.

Bosnia and Herzegovina: Stability has been established. Nevertheless, additional banking sector contingency planning for crisis preparedness, strengthening of banking supervision and bank stress tests are needed.

Further progress is being made to strengthen bank supervision and the crisis resolution framework.

Bulgaria: The financial system, dominated by the banking sector, remains stable, well capitalized and highly liquid, and so are individual banks.

Continued prudent regulation and adequate capital buffers will help maintain financial system stability.

Croatia: Strong regulation, supervision, and cooperation with other supervisory authorities remain essential to preserve financial stability.

The high capital adequacy of the banking sector sufficiently ensures its resilience to potential shocks.

Greece: The BoG has placed all undercapitalized non-core banks under enhanced supervision.

Greece has finalized the banking sector recapitalization framework, and introduced reforms to strengthen governance and they will proceed with the recapitalization of banks, in order to enable them to start lending again.

Italy: Italy is vulnerable to contagion from the euro area crisis and financial distress. Banks have strengthened their capital positions, but progress varies across institutions. Banks need to maintain adequate capital and liquidity buffers to remain elastic to the downturn.

During 2011 Italian banks had significantly strengthened their capital base, for the five largest banking groups (covering about 70 percent of total consolidated assets), the core tier 1 capital ratio get increased. 
Republic of Kosovo: The banking sector remains well-capitalized, liquid, and profitable, despite the increase in nonperforming loans that maybe relates to the economic slowdown. Legal protection for banking supervisors and other CBK employees needs to be strengthened.

Macedonia, FYR: The banking sector remains well-capitalized and highly liquid, with a stable domestic financing.

Montenegro: During 2011 the situation in the banking sector improved significantly. Tightened regulation pressed foreign owners to recapitalize their banks and to ensure appropriate liquidity in the system. Banks sold bad loans to parents or factoring companies.

Romania: The banking sector is vulnerable to spillovers from the euro area and the weak economic recovery. The Romanian banking sector maintains reassuring capital buffers and provisions but continues to be vulnerable to spillovers from the ongoing euro area crisis. The banking system remains well capitalized.

Serbia: The banking system remains liquid and well capitalized owing to cautious prudential policies pursued before and during the crisis. The NBS intends to continue improving the regulatory and supervisory framework in line with international best practice and plans to adopt the Basel II framework by 2011.

\section{References:}

Bank of Albania, www.bankofalbania.org

National Bank of the Republic of Kosovo, www.bqk-kos.org

Bank of Italy, www.bancaditalia.it

Bank of Greece, www.bankofgreece.gr

Bulgarian National Bank, www.bnb.bg

Central Bank of Bosnia and Herzegovina, www.cbbh.ba

National Bank of Serbia, www.nbs.rs

National Bank of the Republic of Macedonia, www.nbrm.gov.mk

National Bank of Romania, www.bnro.ro

IMF Country Report (2013), Albania, Washington, D.C.: International Monetary Fund

IMF Country Report (2012), Republic of Kosovo, Washington, D.C.: International Monetary

Fund

IMF Country Report (2012), Bulgaria, Washington, D.C.: International Monetary Fund

IMF Country Report (2012), Romania, Washington, D.C.: International Monetary Fund

IMF Country Report (2012), Croatia, Washington, D.C.: International Monetary Fund

IMF Country Report (2012), Serbia, Washington, D.C.: International Monetary Fund

IMF Country Report (2012), Montenegro, Washington, D.C.: International Monetary Fund

IMF Country Report (2013), Bosnia and Herzegovina, Washington, D.C.: International

Monetary Fund

IMF Country Report (2013), Former Yugoslav Republic of Macedonia, Washington, D.C.:

International Monetary Fund

IMF Country Report (2013), Slovenia, Washington, D.C.: International Monetary Fund

Indian Institute of Banking Finance (IIBF) (2010), Bank. Financial Management

Frederic S.MISHKIN, Stanley G.EAKINS (sixth edition, 2009), "Financial Market and Institution"

EBCI (2012), "Working group on Bazel III Implementation in Emerging Europe", European Bank Coordination "Viena" Initiative.

"The Financial Market and Institution" Frederic S. Mishkin, Stanley G. Eakins, (Fifth edition, 2006)

Frederic S. Mishkin (2006), "The Next Great Globalization. How Disadvantaged Nations can Harness Their Financial Systems to Get Rich?” 
Rose-Hudkins, (Seventh Edition, 2008), "Bank Management and Financial Services"

Morton Glantz, 2003, "Managing Bank Risk"

J. Bessis, 2003, "Risk Management"

T.Koch, (3th edition 2005), "Bank Management" 